\title{
Collagenolytic Activity of Aerobic Halophiles from Hides
}

\author{
By JENNIFER A. THOMSON, D. R. WOODS AND \\ R. L. WELTON \\ Department of Botany and Microbiology, Rhodes University, \\ Grahamstown, South Africa
}

(Accepted for publication I2 November 197I)

\begin{abstract}
SUMMARY
The collagenolytic activity of $\mathrm{I} I 0$ aerobic halophilic and halotolerant bacterial strains isolated from cured hides was determined. At $2 \cdot 34 \%$ (w/v) $\mathrm{NaCl}, 10 \%$ of the bacterial strains could denature purified collagen. Collagenolytic activity was not detected at $7 \%(\mathrm{w} / \mathrm{v}) \mathrm{NaCl}$. Three of the collagenolytic strains were identified as Bacillus spp. and eight as Achromobacter spp. Nine of these eleven bacteria were also gelatinolytic. Australian hides which produce decay-free leather lacked collagenolytic bacteria.
\end{abstract}

\section{INTRODUCTION}

Since leather decay is attributed to bacterial degradation of collagen, the incidence of collagenolytic bacteria in cured hides is important. Although pure collagen is not denatured by common proteolytic enzymes, it may be denatured by specific collagenases or by physical and chemical means. Denatured collagen (gelatin) is susceptible to many proteolytic enzymes. Unfortunately, frequent use of unsuitable denatured substrates has resulted in erroneous reports of collagenolytic activity (Mand1, I96I). Eight bacterial strains have been shown to have collagenolytic activity under anaerobic conditions (Waldvogel \& Swartz, 1969). The only report of collagenolytic activity in aerobic bacteria, as judged by denaturation of purified collagen, implicated two strains of Pseudomonas (Adamcic \& Clark, 1970).

The present study was undertaken to determine the incidence of collagenolytic halophilic and halotolerant bacteria in hides. The salt requirements and gelatinolytic activity of the bacteria were also investigated.

\section{METHODS}

Bacterial isolation. Plugs, $2 \mathrm{~cm}$ in diameter, were taken from ro randomly selected hides from eight different batches at a tannery (Woods, Atkinson, Cooper \& Galloway, 1970 b). Two of the hide batches were from different Australian curers and the remainder from six different South African curers. Five plugs from each hide sample were cut into pieces and soaked in $50 \mathrm{ml} 10 \%(\mathrm{w} / \mathrm{v}) \mathrm{NaCl}$ at 4. for three days prior to plating on $10 \% \mathrm{NaCl}$ agar to obtain isolated bacterial colonies.

Media. (Note: all percentage compositions are w/v unless otherwise stated.) Aerobic bacteria were cultured on 0.85 , IO I 5 and $20 \% \mathrm{NaCl}$ agar (Woods, Atkinson, Cooper \& Galloway, 1970a). Facultative anaerobes were cultured on 0.85 and $10 \% \mathrm{NaCl}$ agar with 0. I I \% sodium thioglycollate. Anaerobic cultures were placed in Brewer jars under $98 \% \mathrm{~N}_{2}$ and $2 \% \mathrm{H}_{2}(\mathrm{v} / \mathrm{v})$. Cultures were incubated at $35^{\circ}$.

Gelatinolytic activity. Bacterial strains were grown on 0.85 and $10 \% \mathrm{NaCl}$ agar containing $0.25 \%$ gelatin. Utilization of gelatin was determined by flooding with acidified $15 \% \mathrm{HgCl}_{2}$ (Cowan \& Steel, I965).

Preparation of collagen. Neutral-salt-soluble collagen extracted from calf skin and puri- 


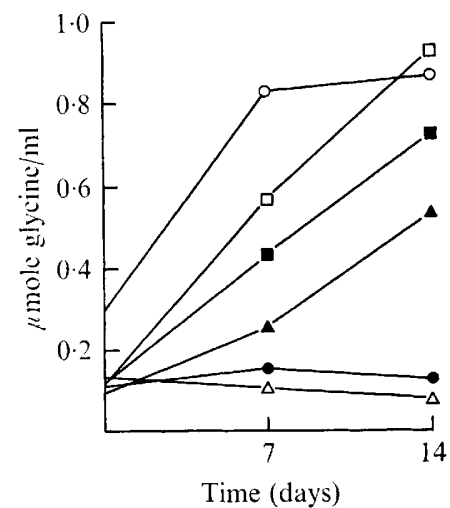

Fig. I

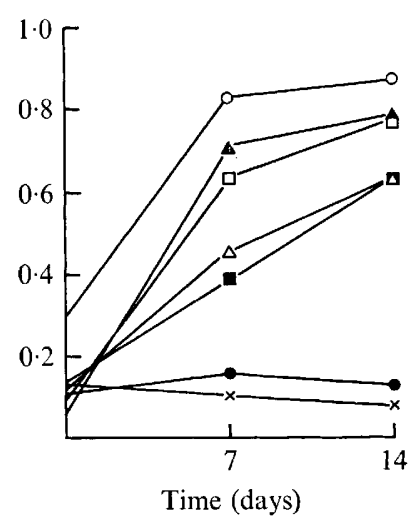

Fig. 2

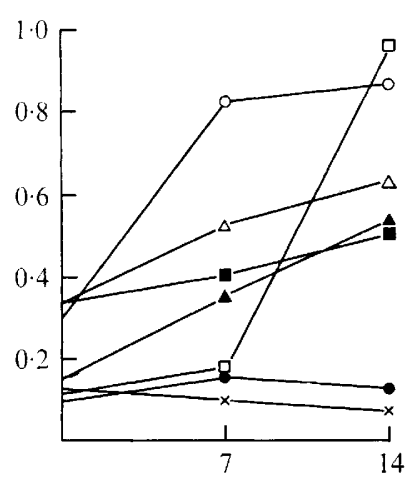

Time (days)

Fig. 3

Fig. I. Collagenolytic activity of Bacillus spp. I, 2 and 3 at $2 \cdot 34 \%(\mathrm{w} / \mathrm{v}) \mathrm{NaCl}$ under aerobic conditions. $\bigcirc-\bigcirc$, Clostridium histolyticum collagenase + collagen; $\triangle \longrightarrow \triangle$, uninoculated collagen; - - bacteria + buffer; $\square-$, Bacillus sp. I + collagen; $\Delta-\mathbf{\Delta}$, Bacillus sp. $2+$ collagen; $\square-\square$, Bacillus sp. 3 + collagen. For clarity, zero time symbols have been omitted.

Fig. 2. Collagenolytic activity of Achromobacter spp. I, 2 and 3 at $2 \cdot 34 \%(\mathrm{w} / \mathrm{v}) \mathrm{NaCl}$ under aerobic conditions. $\mathrm{O}-\mathrm{O}$, Clostridium histolyticum collagenase + collagen; $\times-\times$, uninoculated collagen; - - - bacteria + buffer; $\mathbf{-}-\mathbf{-}$, Achromobacter sp + collagen; $\boldsymbol{\Lambda}-\boldsymbol{\Lambda}$, Achromobacter sp. $2+$ collagen; $\square-\square$, Achromobacter sp. $3+$ collagen; $\triangle \longrightarrow \triangle$, Achromobacter sp. $4+$ collagen. For clarity, zero time symbols have been omitted.

Fig. 3. Collagenolytic activity of Achromobacter spp. 5, 6, 7 and 8 at $2 \cdot 34 \%(\mathrm{w} / \mathrm{v}) \mathrm{NaCl}$ under aerobic conditions. $\bigcirc-0$, Clostridium histolyticum collagenase + collagen; $\times \longrightarrow \times$, uninoculated collagen; - - bacteria + buffer; $\square-\mathbf{\square}$, Achromobacter sp. $5+$ collagen; $\boldsymbol{\Lambda}-\mathbf{\Delta}$, Achromobacter sp. $6+$ collagen; $\square-\square$, Achromobacter sp. $7+$ collagen; $\triangle \longrightarrow \triangle$, Achromobacter sp. $8+$ collagen. For clarity, zero time symbols have been omitted.

fied by the method of Cooper \& Davidson (1965) was used. The collagen was kept at $4^{\circ}$ in the lyophilized form. A $0.2 \%$ solution of the collagen in $0.4 \mathrm{M}(2.34 \%) \mathrm{NaCl}, 0.0 \mathrm{I}$ M-tris, $0.002 \mathrm{M}^{-\mathrm{CaCl}_{2}}, \mathrm{pH} 7 \cdot 6$, was prepared by the method of Waldvogel \& Swartz (1969).

Screening for collagenolytic activity. The method of Adamcic \& Clark (1970) was followed, but modifications were made due to the high salt concentrations used. To $3 \mathrm{ml}$ of $0.02 \%$ collagen solution in $2.34 \% \mathrm{NaCl}, 0.0 \mathrm{I} \mathrm{M}$-tris, $0.002 \mathrm{M}-\mathrm{CaCl}_{2}$ and $7 \% \mathrm{NaCl}, 0.0 \mathrm{I} \mathrm{M}-$ tris, $0.002 \mathrm{M}-\mathrm{CaCl}_{2}$ at $\mathrm{pH} 7.6$ was added $0 . \mathrm{I} \mathrm{ml}$ of a bacterial suspension in buffer containing $10^{9}$ bacteria $/ \mathrm{ml}$. Inoculated solutions were incubated aerobically and assayed for release of amino acids after 7 and I4 days using a ninhydrin colorimetric analysis (Rosen, 1957). Extinctions were read on a Unicam SP 800 spectrophotometer at $570 \mathrm{~nm}$. Controls at both 2.34 and $7 \% \mathrm{NaCl}$ consisted of: $(a)$ uninoculated collagen, $(b)$ six bacterial strains, chosen at random, in buffer without collagen, (c) Clostridium histolyticum collagenase form II (Koch-Light Laboratories, Colnbrook, Buckinghamshire) in the proportion enzyme: collagen, I : Io. Collagenolysis was determined by comparing the amount of amino acids released with that of the uninoculated controls and expressed as $\mu$ moles glycine $/ \mathrm{ml}$.

Identification of strains. Collagenolytic strains were classified according to Bergey's Manual of Determinative Bacteriology (Breed, Murray \& Smith, 1957). 
Table I. Characteristics of collagenolytic Bacillus strains

\begin{tabular}{|c|c|c|c|}
\hline & & ain $n$ & \\
\hline & I & 2 & 3 \\
\hline Gram-variable rods & + & - & + \\
\hline Gram-positive rods & - & + & - \\
\hline Endospores & + & + & + \\
\hline Capsules & - & - & - \\
\hline Motility & + & + & + \\
\hline Catalase and oxidase & + & + & + \\
\hline Gelatinolytic activity & + & + & + \\
\hline Starch hydrolysis & - & - & - \\
\hline $\begin{array}{l}\text { Production of acid, not gas from } \\
\text { glucose, sucrose, mannose }\end{array}$ & + & + & + \\
\hline Action on lactose & - & - & - \\
\hline Nitrate reduction & + & + & + \\
\hline Indole production & - & - & - \\
\hline Obligate aerobe & - & + & + \\
\hline Facultative anaerobe & + & - & - \\
\hline Length $(\mu \mathrm{m})$ & $\mathrm{I} \cdot 8$ & $\mathrm{I} \cdot 8$ & $1 \cdot 6$ \\
\hline $\begin{array}{l}\text { Halotolerant with optimal NaCl } \\
\text { concentration of } 2 \cdot 34 \%(w / v)\end{array}$ & + & + & + \\
\hline
\end{tabular}

RESULTS

\section{Salt requirements of bacterial strains}

Of I 40 strains isolated, $5 \mathrm{I}$ were halotolerant (salt range of 0.85 to $20 \%$ ) and 89 halophilic (salt range of 7 to $15 \%$ or $20 \%$ ).

\section{Collagenolytic activity}

Eleven of I Io strains tested ( 76 South African, 34 Australian) at $2 \cdot 34 \% \mathrm{NaCl}$ showed collagenase activity under aerobic conditions. None of the I 28 strains tested at $7 \% \mathrm{NaCl}$ showed collagenolytic activity. Although the bacteria were isolated and subcultured for many generations on collagen-free media, only one strain, Achromobacter sp. 7, showed a long lag phase characteristic of the enzyme produced by one of the two Pseudomonas strains reported by Adamcic \& Clark (1970). Significant enzymatic activity of the other strains was already detectable after seven days (Fig. I to 3). Collagenolytic activity was not observed when strains were tested in buffer without $\mathrm{CaCl}_{2}$ (Gallop, Seifter \& Meilman, I957). The I I collagenolytic strains were isolated from South African hides from five curers. The Australian hides, from two curers, did not contain collagenolytic bacteria. Thus the percentage of bacteria with collagenase from South African hides was I $4.47 \%$ compared with I0 \% for all strains tested.

\section{Gelatinolytic activity}

Of the I I collagenolytic strains, the nine halotolerant ones, growing from 0.85 to $20 \%$ $\mathrm{NaCl}$ had gelatinolytic activity while the two strains showing poor growth at $0.85 \% \mathrm{NaCl}$ had no gelatinolytic activity. Thus degradation of gelatin by a bacterial strain is not necessarily an indication of collagenolytic activity. 
Table 2. Characteristics of collagenolytic Achromobacter strains

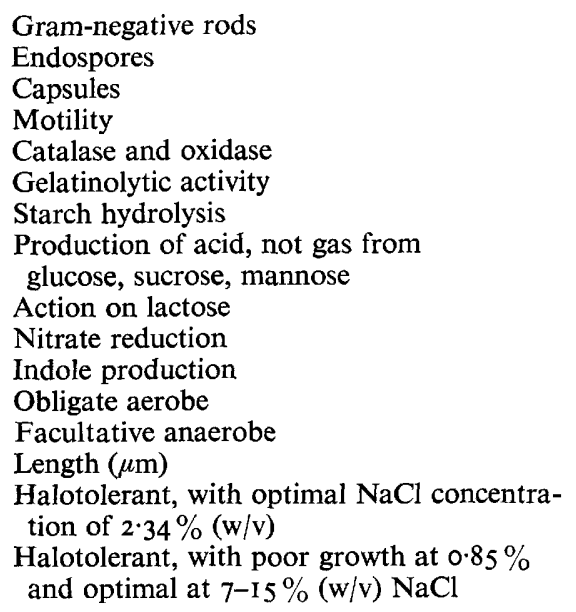

\begin{tabular}{|c|c|c|c|c|}
\hline \multicolumn{5}{|c|}{ Strain no. } \\
\hline $\mathbf{I}$ & $2,3,4$ & 5,6 & 7 & 8 \\
\hline+ & + & + & + & + \\
\hline- & - & - & - & - \\
\hline+ & + & - & - & + \\
\hline- & - & - & - & - \\
\hline+ & + & + & + & + \\
\hline+ & + & + & - & - \\
\hline- & - & - & - & - \\
\hline+ & + & + & + & + \\
\hline- & - & - & - & - \\
\hline+ & + & + & + & + \\
\hline+ & - & - & - & + \\
\hline+ & - & - & - & - \\
\hline- & + & + & + & + \\
\hline $\mathrm{I} \cdot 4$ & $I \cdot 2$ & $\mathrm{I} \cdot 6$ & $\mathrm{I} \cdot 4$ & I. 6 \\
\hline+ & + & + & - & - \\
\hline- & - & + & - & + \\
\hline
\end{tabular}

\section{Identification of collagenolytic strains}

Three of the collagenolytic strains were identified as Bacillus spp. and eight as Achromobacter spp. Their characteristics are shown in Tables I and 2.

\section{DISCUSSION}

Aerobic collagenolytic activity was shown in I I bacteria which appear to belong to eight different species. Conclusive demonstrations of true bacterial collagenases have been demonstrated only in four Clostridium spp., three Bacteriodes spp., one strain of Staphylococcus aureus and two strains of Pseudomonas (Jennison, I947; Neuman \& Tytell, 1950; Gibbons \& MacDonald, I96I; Waldvogel \& Swartz, I969; Adamcic \& Clark, I970).

The increased activity of the collagenase enzyme at $2 \cdot 34 \% \mathrm{NaCl}$ indicates that although the bacteria are tolerant of a wide range of salt concentrations, there is an optimal salt concentration for enzymatic activity. The lack of activity at $7 \% \mathrm{NaCl}$ is likely to be due to an inability to produce the enzyme at that salt concentration or to the inactivation of the enzyme by salt. Inhibition of enzymes by salt concentrations greater than $3 \%$ has been shown in extremely halophilic bacteria which have an optimal salt concentration for growth of $20 \%$ (Louis \& Fitt, I97I).

The observation that no Australian bacteria utilized collagen is important as it has been reported that Australian hides produce uniformly good leather with little hide decay (Hendry, Cooper \& Woods, 1970).

The authors wish to acknowledge the assistance of Miss S. Meldrum, Dr D. R. Cooper, the Leather Industries Research Institute, Grahamstown and King Tanning Company. J.A.T and R.L.W. wish to acknowledge Council for Scientific and Industrial Research Post-Graduate Bursaries and J.A.T. a Rhodes University Research Scholarship. 


\section{REFERENCES}

AdamciC, M. \& CLARK, D. S. (I970). Collagenolytic activity of pigmented pseudomonads, Canadian Journal of Microbiology 16, 709-7I 2.

Breed R. S., Murray. E. G. D. \& Smith, N. R. (1957). Bergey's Manual of Determinative Bacteriology,

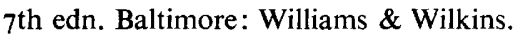

COOPER, D. R. \& DAvidson, R. J. (1965). The effect of ultraviolet irradiation on soluble collagen. Biochemical Journal 97, I39-I47.

CowAN, S. T. \& STEEL, K. J. (1966). Manual for the Identification of Medical Bacteria, p. I56. London: Cambridge University Press.

Gallop, P. M., Seifter, S. \& Meilman, E. (1957). Studies on collagen. I. The partial purification, assay, and mode of activation of bacterial collagenase. Journal of Biological Chemistry 227, 89 I-906.

Gibbons, R. J. \& MACDonald, J. B. (196I). Degradation of collagenous substrates by Bacteriodes melaninogenicus. Journal of Bacteriology 8I, 6I4-62 I.

Hendry, M. F., CoOPER, D. R. \& Woods, D. R. (1970). The microbiology of curing and tanning processes, part IV. The laboratory screening of antiseptics. Journal of the American Leather Chemists' Association 66, $3 \mathrm{I}-39$.

Jennison, M. W. (1947). The collagenase activity of culture filtrates of Clostridium histolyticum. Journal of Bacteriology 54, 55-56.

Louis, B. G. \& FITT, P. S. (I97I). Nucleic acid enzymology of extremely halophilic bacteria. cutirubrum $H$. DNA-dependent RNA polymerase. Biochemical Journal 121, 62 I-627.

MANDL, I. (1961). Collagenases and elastases. In Advances in Enzymology, pp. 163-264. Edited by F. F. Nord. New York: Interscience Publishers, Inc.

Neuman, R. E. \& Tytell, A. A. (I950). Action of proteolytic enzymes on collagen. Proceedings of Society of Experimental Biology and Medicine 73, 409-4I 2.

RoSEN, H. (1957). A modified ninhydrin colorimetric analysis for amino acids. Archives of Biochemistry and Biophysics 67, 10-15.

Waldvogel, F. A. \& SWARTZ, M. N. (I969). Collagenolytic activity of bacteria. Journal of Bacteriology $\mathbf{9 8}$, $662-667$.

Woods, D. R., Atkinson, P., Cooper, D. R. \& Galloway, A. C. (1970a). The microbiology of curing and tanning processes, part I. The estimation of aerobic bacterial contamination in curing and tanning processes. Journal of the American Leather Chemists' Association 65, 125-134.

Woods, D. R., Atkinson, P., Cooper, D. R. \& Galloway, A. C. (1970 $b$ ). The microbiology of curing and tanning processes, part III. Analysis of aerobic bacteria in agitated hide brining. Journal of the American Leather Chemists' Association 65, 410-4I8. 